RESEARCH ARTICLE

\title{
Characterization of fungal pathogens causing anthracnose in capsicum pepper (Capsicum annuum L.) and their seed borne nature
}

\author{
W.A. Welideniya ${ }^{1}$, K.D.R.C. Rienzie ${ }^{2}$, W.A.R.T. Wickramaarachchi ${ }^{3{ }^{*}}$ and A.G.B. Aruggoda ${ }^{1}$ \\ ${ }^{1}$ Department of Agricultural and Plantation Engineering, Faculty of Engineering Technology, The Open University of \\ Sri Lanka, Nawala, Nugegoda 11222, Sri Lanka \\ ${ }^{2}$ Agribusiness Centre, Faculty of Agriculture, University of Peradeniya, Peradeniya 20400, Sri Lanka \\ ${ }^{3}$ National Plant Quarantine Service, Canada Friendship Road, Katunayake 11450, Sri Lanka
}

Received: 17/01/2019; Accepted: 08/07/2019

\begin{abstract}
Anthracnose caused by Colletotrichum spp. is a troublesome disease in all Capsicum spp. including capsicum pepper (Capsicum annuum L.), causing severe losses at both the pre-harvest and post-harvest stages. It is common throughout the world. In Sri Lanka, capsicum pepper is likely to be infected by both Colletotrichum capsici (Colletotrichum truncatum) and C. gloeosporioides, resulting in a reduction in the quantity and quality of the harvest. A detailed investigation was carried out to identify the different species of Colletotrichum that infect capsicum pepper, and the nature of this infection by employing standard tests. Colletotrichum capsici and C. gloeosporioides were isolated from the capsicum pepper seed samples collected from three different agro ecological regions in Sri Lanka. When capsicum pepper seeds collected from fruits categorized according to a standard rating scale were tested for germination, a gradual decrease of germination percentages and increased seed infection percentages were observed. After culturing different components of the seeds collected from infected fruits, it was found that both C. capsici and C. gloeosporioides can survive on the seed coat, pericarp and embryo. In addition, Fusarium spp. and Aspergillus spp. were also present in cultures of seed coat but not in cultures of the pericarp and embryo. The study revealed that both $C$. capsici and $C$. gloeosporioides can invade the important parts of the seeds internally and externally, causing higher germination losses, during both the pre and post emergence stages of capsicum pepper; the Aspergillus spp. and Fusarium spp. were only seed borne externally.
\end{abstract}

Keywords: Anthracnose, Capsicum pepper, Capsicum annuum L., Colletotrichum capsici, Colletotrichum gloeosporioides, Seed borne pathogens.

\section{INTRODUCTION}

Capsicum pepper (Capsicum annuum L.) is a globally important vegetable crop that belongs to the family Solanaceae. It is recorded that the genus Capsicum originated in South America. There is a high market demand for capsicum pepper fruit due to its shape and colour. Kurunegala, Puttalam, Badulla, and Nuwara-Eliya are the major capsicum pepper growing districts in Sri Lanka since a favorable climate prevails in those areas for the growth of capsicum crop. Biotic factors such as pathogens (fungal, bacterial, viral, and nematodal) and insects can cause adverse effects on capsicum pepper cultivation (Senanayake et al., 2013; Kelaniyagoda et al. 2011). In Sri Lanka, bacterial wilt, anthracnose, various viruses, and several insect pests are the major biotic factors that constrain capsicum pepper cultivation. Out of those, anthracnose caused by Colletotrichum spp. accounts for the most significant crop losses globally to capsicum pepper cultivators (Mongkolporn \& Taylor, 2018; Diao et al., 2015). Anthracnose sets in either during the preharvest or post-harvest period causing fruit rot, resulting in extensive losses when Capsicum is grown in tropical and subtropical climates, irrespective of season (AVRDC, 1998). Five species of Colletotrichum have been identified as being responsible for anthracnose disease in Capsicum in various countries. Among these are Colletotrichum capsici, also referred to as Colletotrichum truncatum according to the latest classification (Ranathunge et al., 2012), and C. gloeosporioides, which are the causal agents of anthracnose disease in green chilies (hot pepper) in Sri Lanka (Jayawardana et al., 2015; Rajapakse \& Ranasighe, 2002).

In Sri Lanka, hot chili, which is one of the Capsicum spp. is mostly infected by $C$. capsici, while capsicum pepper is infected by both C. capsici and C. gloeosporioides (Rajapakse \& Ranasighe, 2002). Seed borne nature of $C$. capsici and $C$. gloeosporioides has been proven by many studies throughout the world (Saxena et al., 2016). However, to date, no systematic studies have been conducted on seed borne nature of capsicum pepper anthracnose caused by Colletotricum spp. Furthermore, information on internationally recognized seed health testing procedures, which is a necessary part of the seed certification process for capsicum pepper seeds, is also scarce. Therefore, the present study was commenced with two objectives, namely to identify major fungal pathogens causing anthracnose in capsicum pepper and to evaluate the seed borne nature of Colletotrichum spp. using different seed health testing procedures. 


\section{MATERIALS AND METHODS}

This research was conducted at the Division of Plant Pathology, Horticultural Crop Research and Development Institute (HORDI), Gannoruwa, Peradeniya, Sri Lanka.

\section{Symptoms observed on infected fruits and isolation of fungal pathogens}

Infected and healthy capsicum pepper fruits were randomly collected from three different agro ecological regions (AER), namely Low Country Dry Zone (LCDZ: 20 samples), Mid Country Wet Zone (MCWZ: 20 samples), and Up Country Wet Zone (UCWZ: 20 samples) in Sri Lanka. Fruits were placed in sealed polythene bags after wrapping with clean tissue paper and transported to the Laboratory. The visible symptoms of anthracnose in infected fruits were recorded while the manifestation of symptoms during development of the disease were also recorded with time. Table 1 and Table 2 present the information on healthy and diseased capsicum pepper fruits, respectively. Anthracnose-infected seeds and fruit tissues were cultured in potato dextrose agar (PDA) with $0.01 \%$ Streptomycin, and incubated for 5 days at $25 \pm 1^{\circ} \mathrm{C}$. The mycelia growth and acervuli development around seeds and tissue were observed with the naked eye. Conidial masses suspected to be Colletotrichum spp. were picked from colonies and subcultured in PDA for further purification. Accordingly, seven isolates were designated with a reference number for each isolate. The collected Colletotrichum isolates were named in such a way that the place where the fruits were collected, cultivars, and maturity of the infected pods (whether ripe or unripe) could be identified.

For single spore isolation, spore suspensions from each sub-cultured fungal species were prepared. The concentration of all spore suspensions was adjusted to approximately 10 spores $/ \mu \mathrm{l}$ with a Pipetman microliter pipette. A marker pen was used to draw circles $(3 \mathrm{~mm}$ diameter) on the bottom of each $2 \%$ water agar plate. Ten microliters $(10 \mu \mathrm{l})$ of the spore suspension was placed on the surface of the water agar above each circle. After incubation at $25 \pm 2{ }^{\circ} \mathrm{C}$ for 12 hours, each circle was inspected under a microscope at $100 \mathrm{X}$ magnification through the bottom of the plate. These marked agar areas were cut and transferred to PDA slants using a cork borer under aseptic conditions and incubated at $25 \pm 2{ }^{\circ} \mathrm{C}$. The mycelia growth and acervuli development around seeds and tissue were observed through naked eye. Conidial masses picked from colonies that were suspected to be Colletotrichum spp., were sub cultured in PDA for further purifications. Accordingly, seven isolates were designated with reference numbers for each isolate. The collected Colletotrichum isolates were named using the combination of the place where the fruits were collected, cultivars, and maturity of the infected pods (unripe or ripe).

For single spore isolation, spore suspensions from each sub-cultured fungal species were prepared. The concentrations of the spore suspensions were adjusted to approximately 10 spores $/ \mu \mathrm{l}$ with a Pipetman microliter pipet. A marker pen was used to draw circles ( $3 \mathrm{~mm}$ diam.) on the bottom of each $2 \%$ water agar plate. Ten micro liters $(10 \mu \mathrm{l})$ of the spore suspension was placed on the surface of the water agar above each circle. After incubation at $25 \pm 2{ }^{\circ} \mathrm{C}$ for 12 hours, each circle was inspected under a microscope at $100 \times$ magnification from the bottom of the plate. These marked agar areas were cut and transferred to PDA slants using a cork borer under aseptic conditions and incubated at $25 \pm 2{ }^{\circ} \mathrm{C}$.

\section{Colony and spore morphology}

Two Colletotrichum isolates were grown on PDA plates kept at $25 \pm 2{ }^{\circ} \mathrm{C}$ while subject to dark and light periods alternating every 12 hours. Plugs $(5 \mathrm{~mm})$ were aseptically

Table 1: Capsicum fruits collected from different cultivars from different locations.

\begin{tabular}{lllll}
\hline AER & No. samples & District & Location & Cultivars \\
\hline LCDZ & 20 & Kurunegala & Pure seeds farm (Nikaweratiya) & CA-8 and Bulnose \\
MCWZ & 10 & Kandy & Gannoruwa & CA-8 and Calister \\
MCWZ & 10 & Kandy & Kandy market & Hungarian Yellow Wax (HYW) \\
UCWZ & 20 & Nuwara Eliya & Rahangala & Hungarian Yellow Wax (HYW) \\
\hline
\end{tabular}

Table 2: Sources of seven isolates of Colletotrichum spp. obtained from infected fruits.

\begin{tabular}{|c|c|c|c|c|c|c|}
\hline AER & District & Location & Cultivar & Colletotrichum spp. & Pod stage & Isolate name \\
\hline \multirow{2}{*}{ LCDZ } & \multirow{2}{*}{ Kurunegala } & \multirow{2}{*}{ Nikaweratiya } & CA-8 & C. capsici & Ripe & NW-CA-R \\
\hline & & & Bulnose & C. capsici & Ripe & NW-B-R \\
\hline \multirow{4}{*}{ MCWZ } & \multirow{4}{*}{ Kandy } & Gannoruwa & CA-8 & C. capsici & Ripe & G-CA-R \\
\hline & & & Calister & C. capsici & Ripe & G-C-R \\
\hline & & & Unknown & C. capsici & Ripe & G-UK-R \\
\hline & & Kandy market & HYW & C. gloeosporioides & Unripe & KM-HYW-UR \\
\hline UCWZ & Nuwara Eliya & Rahangala & HYW & C. gloeosporioides & Ripe & HR-HYW-R \\
\hline
\end{tabular}


punched from the edges of actively growing areas of a 5-day-old culture of each isolate. Each plug was placed on PDA plates and incubated under the same conditions as starter cultures. After 7 days, the mean colony growth rate was determined. Colony characteristics of the mycelium such as color were recorded. Colony growth rate and texture were considered for species identification. The morphological characteristics of conidia were determined using 7-day-old fungal cultures. Fungal masses were harvested with sterile distilled water and the spores were observed under a compound light microscope. One hundred spores were measured under a high power objective using calibrated ocular and stage micrometers. Morphological characteristics such of acervuli, setae, and conidia were studied and the average spore sizes were calculated.

\section{Koch's postulates}

Koch's postulates were confirmed with fruits (pin-prick method/10 $\mu \mathrm{L}$ of conidia suspension per wound) by using a 7 day old inoculum grown on PDA at a concentration of $5 \times 10^{5}$ conidia $/ \mathrm{ml}$ standardized with a hemocytometer (Sharma et al., 2005). Re-isolation was performed from the lesions developed on artificially infected fruits. The isolated pathogen was compared with the original culture to prove Koch's postulates.

\section{Determination of the seed borne nature of Colletotrichum spp. using seed health testing procedures}

To discover the effectiveness of different seed health testing methods for detecting seed borne fungi of capsicum pepper, two methods were checked out according to the protocols published by the International Seed Testing Association (ISTA) (Anon, 1996), specifically standard blotter method and water agar method.

\section{Standard blotter method}

Standard Blotter Method developed by Doyer (1938) is a simple, convenient method, which was later approved by the International Seed Testing Association and included in the ISTA Rules of 1966. Accordingly, the seeds are rated using a scale developed for estimating disease severity of Anthracnose, and it includes the following levels: 0- No spots, 1- One or two small spots less than $1 \mathrm{~cm}^{2}$ in size, 3Two or three sunken spots of about $1 \mathrm{~cm}^{2}$ in size, 6- Several bigger spots above $1 \mathrm{~cm}^{2}$ in size, 9- More than half of entire surface of pod covered with discoloured or black spots and in a rotting state. Four hundred and fifty seeds infected by $C$. capsici (CA-8) and C. gloeosporioides (HYW) for each rating scale were tested by employing standard blotter method in three replicates of 150 seeds each (six plates with 25 seeds). Three circular pieces of blotting paper 90 $\mathrm{mm}$ in diameter were moistened with distilled water, and placed in $90 \mathrm{~mm}$ diameter sterilized culture plates after draining the excess water. 25 untreated seeds were placed and distributed uniformly on each culture plate so they were spaced equally. The plates were then incubated at room temperature $\left(25 \pm 2^{\circ} \mathrm{C}\right)$ under alternate periods of 12 $\mathrm{hr}$ light and $12 \mathrm{hr}$ darkness. After eight days of incubation, the seeds were examined under a light microscope to identify the associated fungi and to check their growth. Further confirmation of seed borne fungi was obtained by using a compound light microscope with temporary slides of the fungi. Disease incidence of fungi was calculated on a percentage basis by using the formula, (No. of infected seeds/ Total no. of seeds examined) X 100.

\section{Water agar method}

Four hundred and fifty seeds infected with C. capsici (CA8) and C. gloeosporioides (HYW) were tested for each rating scale by placing 10 seeds per culture plate containing $20 \mathrm{ml}$ of $2 \%$ agar; there were 3 replicates of 150 seeds each (15 plates with 10 seeds). The culture plates were incubated for 7 days and their fungal growth was examined under a dissecting microscope. The disease incidence was calculated using the same formula as described in the Standard Blotter Method.

Seed borne nature of C. capsici and C. gloeosporioides on seed quality parameters (pot culture studies)

Pot culture test was employed to test the transmissibility of pathogens from seeds to progeny plants potted with sterilized sand, topsoil, and compost in a $1: 1: 1$ ratio (Dahanayake et al., 2012). A hundred seeds from each of the samples infected with $C$. capsici (CA-8) and $C$. gloeosporioides (HYW) were sown separately at the rate of 30 seeds per pot with 10 replicates. Seeds were misted with water and the pots were covered using transparent polyethylene sheets. Healthy seeds from varieties CA-8 and HYW were sown in pots to serve as controls. After 30 days, the symptoms were recorded and the germination rate, pre-emergence losses, and post emergence losses were calculated percentage-wise as described in Khare (1996).

Seed borne nature of C. capsici and C. gloeosporioides on seed quality parameters (Seedling symptom test)

Capsicum pepper seed samples infected with $C$. capsici (CA-8) and C. gloeosporioides (HYW), as well as healthy seeds were examined separately for seedling symptom test. Culture tubes were filled with $30 \mathrm{ml}$ aliquots of $2 \%$ water agar. Three hundred seeds from each sample were placed individually in each tube (ten seeds per replicate) and incubated at $25 \pm 2{ }^{\circ} \mathrm{C}$ under alternating $12 \mathrm{hr}$ light and dark periods for 21 days. Once the seedlings reached the tube brim, the cotton plug was removed and observations were recorded based on symptoms evident in the seedlings: percentage germination, pre-emergence losses and post emergence losses (Khare, 1996).

\section{Determination of location of fungi in seeds}

The location of fungi in seeds was studied by employing the component plating technique as described by Maden et al., (1975). Seed samples naturally infected from $C$. capsici (CA-8) and C. gloeosporioides (HYW), as well as healthy seeds were used separately in this study. Twentyfive seeds were washed four times with tap water, and surface sterilized in $1 \%$ sodium hypochlorite solution for 2 minutes. The seeds were again washed with sterile water and soaked in water for $2 \mathrm{hr}$. Then the seeds were dissected aseptically using sterile needles and forceps. The 
separated seed coat, pericarp, and embryo were placed immediately on water agar plates to prevent tissue drying. Healthy seed parts were used as the control. The plates were then incubated under room temperature $\left(25 \pm 2{ }^{\circ} \mathrm{C}\right)$ under alternating $12 \mathrm{hr}$ light and $12 \mathrm{hr}$ dark periods. After seven days, the seed components were examined under a dissecting microscope to check for the presence of fungi in different seed parts. A compound light microscope was used for further confirmation of the pathogen.

\section{Statistical analysis of data}

All experiments were designed in accordance with Completely Randomized Design (CRD) approach. Data collected for experiments performed on seed borne nature of Colletotricum spp. using standard blotter method and water agar method were statistically analyzed with ANOVA, while the data obtained for the same experiment using pot culture studies and seedling symptom test methods were analyzed with Student's $t$-test using the SAS statistical software package (version 8) of SAS Institute Inc., Cary, NC, USA.

\section{RESULTS AND DISCUSSION}

Capsicum pepper (Capsicum annuum L.) is a globally important vegetable crop that is reported to be infected frequently by a complex of Colletotrichum species including $C$. fructicola, $C$. siamense, $C$. gloeosporioides, $C$. truncatum, C. acutatum, C. coccodes, C. queenslandicum and $C$. simmondsii. It has also been documented that both C. gloeosporioides and C. capsici are species complexes of which $C$. capsici has several pathotypes that are very destructive. However, up to now, with the exception of $C$. gloeosporioides and C. capsici, there have been no reports on multiple species associated with chili and capsicum anthracnose in Sri Lanka.

\section{Symptoms of infected fruits and isolation of fungal pathogens}

\section{Development of symptoms on fruits}

The symptoms on capsicum pepper fruits usually appear as small round dark brown areas on unripe fruits. These spots enlarge and rapidly develop into a brown superficial discoloration of the skin, which later turn into circular, slightly sunken, and water soaked lesions with darker margins and brown or black central portions as the fruit ripens. Gradually, the lesions coalesce and sparse mycelial growth often appears on the margins of these spots. In the $C$. gloesporioides infected fruits that were tested, an encrustation of salmon orange was observed on the lesion and $C$. capsici generated blackish acervulli, which were arranged in a concentric pattern (Fig. 1).

\section{Colony growth, colony and spore morphology}

Colony growth rate in the cultures of $C$. capsici isolate (G-CA-R) ranged between 5.5-7.5 $\mathrm{mm}$ /day and in C. gloeosporioides (NW-HYW-R), 6-9 mm/day. $C$. gloeosporioides (HR-HYW-R) produced colonies with orange cottony mycelia with alternating concentric rings and the bottom of the PDA culture was brown.

C. capsici (G-CA-R) produced colonies of whitish gray with more whitish aerial mycelial growth and concentric rings. The bottom of the PDA culture was dark brown in colour.

The colonies obtained through single spore isolation technique were scrutinized through the naked eye, while the spores were observed though a light microscope. The C. gloeosporioides isolate produced oblong conidia, which were hyaline, single celled and smooth walled, or tapered at both ends and rounded. Lengths and widths of conidia that were measured were in the range 9-20 $\mu \mathrm{m} X 3-7.5$ $\mu \mathrm{m}$ (Fig. 2). Acervuli were circular to elliptical, measuring from 129 to $281.4 \mu \mathrm{m}$ on average. Setae were erect in habit, measuring 37-89 $\mu \mathrm{m}$ X 1.4-4.0 $\mu \mathrm{m}$ on average. Setae were septate, dark brown, thick walled, circular, and up to $200 \mu \mathrm{m}$ in length. Padmana and Janadhana (2011 and 2012) reported that a colony on PDA was grey in colour, with abundant production of acervuli and conidia. The conidiogenous cells were hyaline, oblong or tapered and were 20 X 3-4 $\mu \mathrm{m}$ in size on average. Setae were produced by most isolates (Fig. 2a). C. capsici isolates produced truncate conidia that were one celled, hyaline, smoothwalled, and with a central oil globule; they were curved in shape, tapering gradually at the ends and with an acute apex. Average size of setae ranged around 18 X 2.5-4 $\mu \mathrm{m}$. Acervuli were circular to elliptical in shape and in the range of 70 to $165 \mu \mathrm{m}$ in size, while the setae were erect in habit and of average dimensions 37-120 $\mu \mathrm{m} \mathrm{X} \mathrm{1.4-4.0}$ $\mu \mathrm{m}$ (Fig. 2b). Various parameters are used to characterize anthracnose at species level. Sangdee et al. (2011) used morphological characteristics and pathogenic variability of

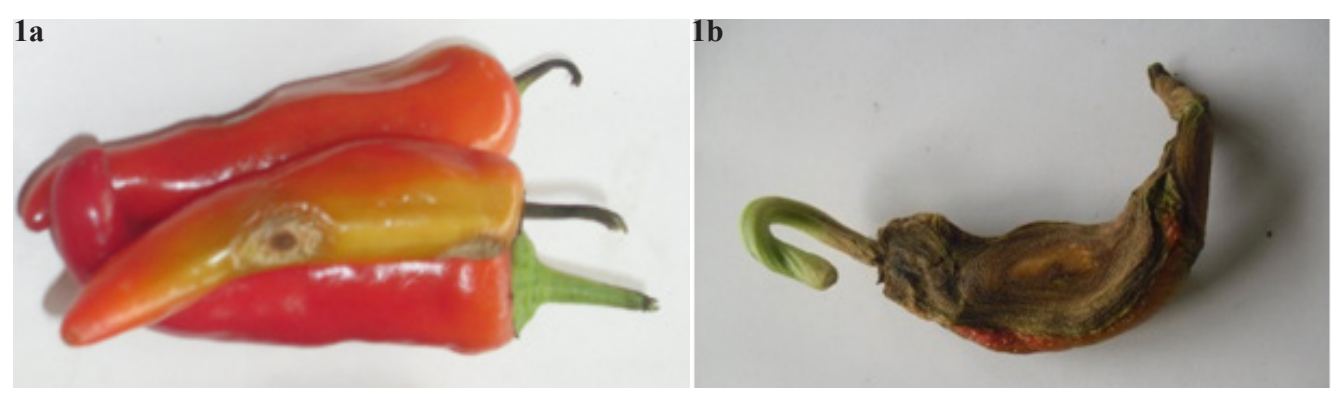

Figure 1: Anthracnose symptoms on capsicum pepper pods. 1a: C. gloeosporioides symptoms (sunken lesions on ripe fruits) on HYW; 1b: C. capsici symptoms (distorted fruit: CA-8). 


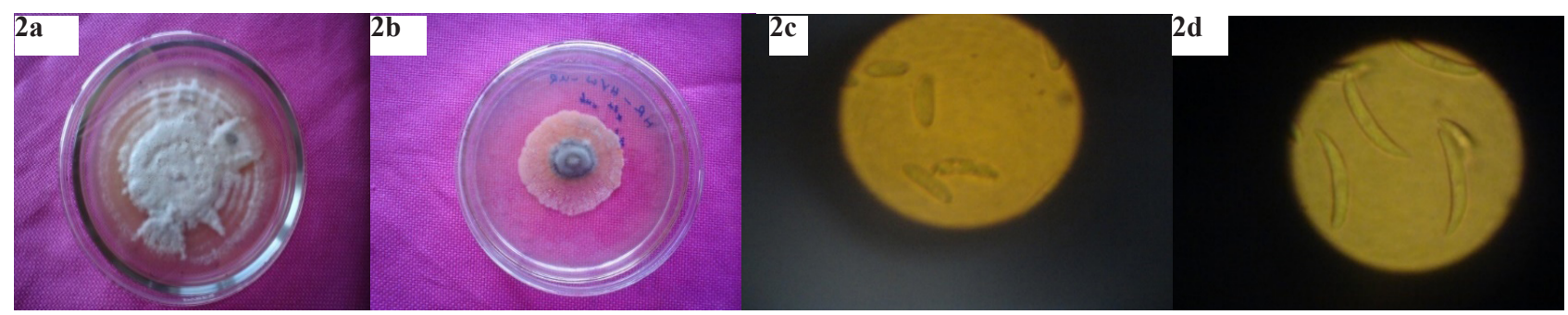

Figure 2: Pure cultures; C. gloeosporioides 2a: C. gloeosporioides and 2b: C. capsici and conidia; 2c: C. gloeosporioides and 2d: $C$. capsici.

fruits to characterize C. capsici infecting chili in Thailand, while Rajapakse and Ranasinghe (2002) characterized five isolates of Colletotrichum spp. using the colour, texture and appearance of colonies, along with the shape, size, and colour of acervuli.

Photita et al. (2005) isolated and identified 34 Colletotrichum spp. from various horticultural crops using colony morphology, and based on size and shape of appressoria and conidia. The genetic basis of the majority of Colletotrichum species has not yet been revealed in most of the Asian countries. Thus, having molecular evidences would be highly supportive when identifying pathogens. Primers that are designed based on ITS, $\beta$-tubulin, ACT, and GAPDH genes can be used to identify these species and are widely applied with other methods of identification; these methods have a greater level of sensitivity and specificity over conventional methods. However, such DNA based methods are complicated, and the associated cost factor is also high (Walcott, 2003), while it is also not possible to get an understanding on other parameters such as germinability, pre-emergence and post emergence infection. Therefore, employing a polyphasic methodology would increase the effectiveness of the process (Hunupolagama et al., 2017).

\section{Confirmation of Koch's postulates using fruit inoculation test}

Numerous oval or circular water soaked spots were observed on capsicum pepper fruits after seven days of inoculation. The fungus was re-isolated from such lesions and the culture obtained was found to be the same as that of the original culture of C. capsici and C. gloeosporioides.

\section{Seed borne nature of the fungal pathogens}

Researchers have employed various seed health testing methods. Standard blotter method (Rathod et al., 2012; Nagaraja \& Krishnappa, 2006), agar plate and seed wash methods (Rathod et al., 2012), and deep-freezing method (Nahar et al., 2004) are popular seed screening methods when testing for pathogens. Each of these methods possesses advantages as well as disadvantages, depending on the nature of seeds of the crop species tested and resource availability. Standard blotter method, agar plate method and paper towel methods are widely used seed testing methods in Sri Lanka (Priyantha et al., 2016).

\section{Standard blotter and water agar methods}

Seed samples from healthy and infected capsicum pepper fruits were categorized based on the rating scale used.
Accordingly, infected seeds with $C$. capsici (capsicum pepper variety: CA-8) and C. gloeosporioides (varieties: CA-8 and HYW) were used for the evaluation of seed borne nature of the pathogens. Results obtained through two seed health testing methods revealed that seed germination was significantly reduced in line with the severity of infection of pods. Germination of seeds obtained from apparently healthy pods displayed a $77.77 \%$ germination rate with standard blotter method and $68.82 \%$ with the water agar method. However, germination of seeds obtained from highly infected pods with anthracnose was reduced in both methods to $37.03 \%$ (corresponding to standard scale level 9) with standard blotter method and $12.82 \%$ (corresponding to standard scale level 9) with water agar method, respectively. These values were statistically significant to germination percentages corresponding to other levels from 0 to 3 , except level 6 . Infection percentage of seeds in C. capsici using standard blotter method gradually increased with the level of infection of pods from which the seeds were obtained. Accordingly, highest seed infection percentage of $46.89 \%$ was recorded with respect to C. capsici, while it was $61.25 \%$ for $C$. gloeosporioides. These percentages were significantly different from other corresponding percentages (0-6) of the scale. These seeds were collected from highly infected pods that were rated 9 on the rating scale (Table 3 ).

According to Vinaya et al. (2009), among different seed health testing methods experimented with, standard blotter method proved the most efficient for quick and accurate diagnosis of $C$. capsici. Standard blotter method indicated a greater incidence of fungi on seed parts followed by agar plate and deep-freezing methods (Alves \& Pozza, 2009), but the agar plate method was found most suitable for the isolation of saprophytic fungi from maize (Niaz \& Dawar, 2009). Bhale et al. (2000) reported that the test tube water agar seedling symptom test was a better method for detecting pathogens in seedlings. In Thailand, Sangchote and Juangbhanich (1984) confirmed the preference of $C$. capsici for the seed coat using blotter and agar methods. According to Sharfun-Nahar et al. (2004), occurrence of fungal species is detected more frequently using blotter test, compared to deep-freezing method in the case of both seeds and pericarps. Kumar et al. (2004) reported that $C$. capsici is transmitted to young seedlings through inoculum developed on infected seeds by local contact. The seed testing methods employed in the present study also can be further recommended for detecting $C$. capsici and $C$. gloeosporioides infections in capsicum pepper. Asalmol et al. (2001) reported that the seed borne fungi of chili were 
capable of causing pre-emergence and post emergence mortality. In keeping with that, the results of this study indicated that the highest mortality (88\%) occurred with C. capsici while the lowest was with Aspergillus flavus (59\%). Similar findings indicating loss in seed germination and reduced vigour of $C$. capsici were reported by Perane and Joi (1988), and Mesta (1996). Yesuf and Sangchote (2004) reported that typical bean anthracnose symptoms became visible on the cotyledon and the first true leaves within a few days after emergence, indicating the important role of seed borne fungus as primary source of inoculum. Many seedlings died within 4-5 days of seed emergence. However, pre-emergence and post-emergence seedling mortality rates were higher in both seed samples of the naturally infected seeds.
Seed borne nature of $C$. capsici on seed quality parameters (pot culture studies)

Results of the experiment presented in Table 4 indicate that naturally infected seed sample manifests lower germination values of $30.00 \%$ (C. capsici) and 33.33\% (C. gloeosporioides) and with higher pre-emergence losses of $70.00 \%$ (C. capsici) and 66.66\% (C. gloeosporioides). In contrast, healthy seeds showed higher germination percentages of $93.33 \%$ and $96.66 \%$, with lower preemergence and post-emergence losses of $6.66 \%$ and $3.33 \%$ respectively for C. capsici and C. gloeosporioides. Student's $t$-test revealed that values obtained for germination, preemergence and post-emergence infection percentages were significantly different for both healthy and infected seeds at $P<0.05$. Results of pot culture test conducted to analyze

Table 3: Seed borne nature of C. capsici and C. gloeosporioides at different levels of infection.

\begin{tabular}{|c|c|c|c|c|}
\hline \multirow[b]{2}{*}{$\begin{array}{c}\text { Rating scale } \\
\text { value }\end{array}$} & \multicolumn{2}{|c|}{$\begin{array}{l}\text { Seed borne nature of } C \text {. capsici } \\
\text { (standard blotter method) }\end{array}$} & \multicolumn{2}{|c|}{$\begin{array}{c}\text { Seed borne nature of } C \text {. gloeosporioides } \\
\text { (Water agar method) }\end{array}$} \\
\hline & Seed germination \% & Seed infection $\%$ & Seed germination $\%$ & Seed infection $\%$ \\
\hline 0 & $77.77^{\mathrm{a}}$ & $0.00^{\mathrm{c}}$ & $68.82^{\mathrm{a}}$ & $0.00^{\mathrm{d}}$ \\
\hline 1 & $67.45^{\mathrm{b}}$ & $3.84^{\mathrm{c}}$ & $58.99^{\mathrm{a}}$ & $28.78^{\mathrm{c}}$ \\
\hline 3 & $46.89^{c}$ & $33.56^{\mathrm{b}}$ & $43.07^{\mathrm{b}}$ & $39.15^{\mathrm{b}}$ \\
\hline 6 & $36.04^{\mathrm{d}}$ & $35.78^{\mathrm{b}}$ & $28.78^{c}$ & $47.04^{b}$ \\
\hline 9 & $37.03^{\mathrm{d}}$ & $46.89^{\mathrm{a}}$ & $12.82^{\mathrm{d}}$ & $61.25^{\mathrm{a}}$ \\
\hline Mean & 58.66 & 24 & 62.39 & 26.66 \\
\hline LSD at 0.05 & 7.979 & 8.597 & 12.07 & 8.024 \\
\hline $\mathrm{CV} \%$ & 8.16 & 19.01 & 16.41 & 13.15 \\
\hline
\end{tabular}

Table 4: Seed borne nature of C. capsici and C. gloeosporioides on seed quality parameters (pot culture studies).

\begin{tabular}{|c|c|c|c|c|c|c|}
\hline \multirow[b]{2}{*}{ Seed category } & \multicolumn{3}{|c|}{ C. capsici } & \multicolumn{3}{|c|}{ C. gloeosporioides } \\
\hline & Germination \% & $\begin{array}{c}\text { Pre } \\
\text { emergence } \\
\text { infection \% }\end{array}$ & $\begin{array}{c}\text { Post } \\
\text { emergence } \\
\text { infection } \%\end{array}$ & $\begin{array}{c}\text { Germination } \\
\%\end{array}$ & $\begin{array}{c}\text { Pre } \\
\text { emergence } \\
\text { infection \% }\end{array}$ & $\begin{array}{l}\text { Post emergence } \\
\text { infection \% }\end{array}$ \\
\hline $\begin{array}{l}\text { Healthy seeds } \\
\text { (Mean) }\end{array}$ & $93.33^{\mathrm{a}}$ & $6.66^{\mathrm{a}}$ & $11.1^{\mathrm{a}}$ & $96.66^{\mathrm{a}}$ & $3.33^{\mathrm{a}}$ & $0^{\mathrm{a}}$ \\
\hline $\begin{array}{l}\text { Infected seeds } \\
\text { (Mean) }\end{array}$ & $30^{\mathrm{b}}$ & $70^{\mathrm{b}}$ & $68.57^{b}$ & $33.33^{b}$ & $66.66^{\mathrm{b}}$ & $27.76^{b}$ \\
\hline
\end{tabular}

Values within a column and not followed by the same letter are significantly different at $(P<0.05)$ according to the Student's $t$-test.

Table 5: Seed borne nature of $C$. capsici and C. gloeosporioides on seed quality parameters (seedling symptom test).

\begin{tabular}{|c|c|c|c|c|c|c|}
\hline \multirow[b]{2}{*}{ Seed category } & \multicolumn{3}{|c|}{ C. capsici } & \multicolumn{3}{|c|}{ C. gloeosporioides } \\
\hline & $\begin{array}{c}\text { Germination } \\
\%\end{array}$ & $\begin{array}{c}\text { Pre } \\
\text { emergence } \\
\text { infection \% }\end{array}$ & $\begin{array}{c}\text { Post } \\
\text { emergence } \\
\text { infection \% }\end{array}$ & $\begin{array}{c}\text { Germination } \\
\%\end{array}$ & $\begin{array}{c}\text { Pre } \\
\text { emergence } \\
\text { infection \% }\end{array}$ & $\begin{array}{c}\text { Post } \\
\text { emergence } \\
\text { infection \% }\end{array}$ \\
\hline Healthy seeds (Mean) & $100^{\mathrm{a}}$ & $0^{\mathrm{a}}$ & $0^{\mathrm{a}}$ & $100^{\mathrm{a}}$ & $0^{\mathrm{a}}$ & $0^{\mathrm{a}}$ \\
\hline Infected seeds (Mean) & $20^{\mathrm{b}}$ & $80^{\mathrm{b}}$ & $100^{\mathrm{b}}$ & $20^{\mathrm{b}}$ & $80^{\mathrm{b}}$ & $100^{\mathrm{b}}$ \\
\hline
\end{tabular}


the seed-to-seedling transmission of $C$. capsici and $C$. gloeosporioides revealed that seedlings that emerged from naturally infected seeds could exhibit severe reduction in the percentage that germinated and higher seedling mortality about 21 days after sowing. Germination was adversely affected by the presence of seed borne fungi. Typical Capsicum anthracnose symptoms on the first true leaves became visible within 3-4 days after emergence.

Seed borne nature of $C$. capsici on seed quality parameters (Seedling symptom test)

Selected seed samples (both healthy and infected) of the varieties HYW and CA-8 were subjected to water agar seedling symptom test to diagnose seed borne infection and to observe the seed-to-seedling disease transmission. Experimental results as shown in Table 5 indicated that naturally infected seeds could suffer a lower germination rate of $20.00 \%$ and higher pre-emergence loss of up to $80.00 \%$. Healthy seeds displayed a higher germination rate of $100 \%$ with no pre- and post-emergence losses. Accordingly, the results were similar in respect of both C. capsici and C. gloeosporioides. Student's $t$-test revealed significant differences $(\mathrm{P}<0.05)$ with respect to germination, pre-emergence and post-emergence infection percentages in the case of both healthy and infected seeds. The infected seed samples exhibited the anthracnose symptoms with the presence of acervuli on the seed coat. These seed samples aborted and failed to germinate while exhibiting seed rot after 21 days of incubation. In this test, after 21 days of incubation, germinated seedlings from the batches of infected seeds developed acervuli on the seed coats that were attached to the cotyledonary leaves. Most of the infected seeds failed to germinate and manifested seed rotting symptoms with increased post-emergence losses.

\section{Location of fungi in seeds}

Naturally infected capsicum pepper seed sample of cultivar CA-8 and HYW were used for the study. The presence of seed borne pathogens in the separated seed parts of both infected and healthy seeds, viz. seed coat, pericarp, and embryo were recorded (Tables 6). Results revealed that both $C$. capsici and $C$. gloeosporioides can reside in seed coat, pericarp and embryo, indicating their internal and external seed borne nature, but C. capsici and C. gloeosporioides were not detected in the seed coat of healthy seeds. Research evidences indicate that both $C$. capsici and C. gloeosporioides could be seed borne, both internally and externally (Gawade, 2013; Hemannavar, 2008). Similarly, Kumar et al. (2004) reported that $C$. capsici could be both externally and internally seed borne and that $C$. capsici and C. gloeosporioides were not visible on the seed coat, pericarp and in embryo of healthy seeds. In contrast, two other fungal species, namely Fusarium and Aspergillus species were associated only with the seed coat, indicating their externally seed borne nature. Both of these genera have been reported to be acting as pathogens and non-pathogens or saprophytes on pepper seeds and fruits (Chigoziri \& Ekefan, 2013; Asalmol et al., 2001). Aspergillus sp. is a commonly found fungal species associated with chili seeds. It is noted for causing reduction in germination by inducing crown rot/ collar rot (Chigoziri \& Ekefan, 2013), while Fusarium acts as a member of the damping off complex in Capsicum spp. Moreover, these pathogens can produce toxins that render agricultural produce unsuitable for consumption.

\section{CONCLUSIONS}

C. capsici and C. gloeosporioides were observed in the seed coat, pericarp, and embryo, whereas Fusarium and Aspergillus were observed only on the seed coat of infected seeds. C. capsici and C. gloeosporioides were not present in the seed coat, pericarp, and embryo of apparently healthy seed samples tested while Aspergillus and Fusarium spp. were visible only in the seed coats of the same seeds. It would be worthwhile to experiment on how these two species would intensify the impact of the infection by acting in combination with $C$. capsici and $C$. gloeosporioides. The study revealed that both $C$. capsici and C. gloeosporioides can invade the important components of the seeds internally and externally, causing higher losses at germination, and at both the pre- and postemergence stages of capsicum pepper, whereas Aspergillus and Fusarium spp. are externally seed borne.

\section{REFERENCES}

Alves, M.D.C. and Pozza, E.A. (2009). Scanning electron microscopy applied to seed-borne fungi examination. Microscopy Research and Technique 72(7): 482-488.

Anonymous (1996). International rules for seed testing. Seed Science and Technology 24: 1-335.

Asalmol, M.N., Kale, V.P. and Ingle, S.T. (2001). Seed borne fungi of chilli, incidence and effect on seed germination. Seed Research 29(1): 76-79.

AVRDC (1998). Annual Report, Asian Vegetable Research and Development Centre, Tainan, Taiwan.

Bhale, U., Bhale, M.S., Pandey, B.R. and Pandey, R.P. (2000). Seed borne fungi of chili in Madhya Pradesh and their significance. Journal of Mycopathological Research 38(2): 117-119.

Chigoziri, E. and Ekefan, E.J. (2013). Seed-borne fungi of Chilli pepper (Capsicum frutescens) from pepper producing areas of Benue state, Nigeria. Agriculture and Biology Journal of America 4: 370-374.

Dahanayake, N., Madurangi, S.A.P., Ranawake, A.L. (2012). Effect of potting mixture on growth and yield of chilli varieties (capsicum spp) and microbial activity. Tropical Agricultural Research and Extension 15 (3): 33-35.

Diao, Y., Zhang, C., Xu, J., Lin, D., Liu, L., Mtung'e, O.G. and Liu, X. (2015). Genetic differentiation and recombination among geographic populations of the fungal pathogen Colletotrichum truncatum from chili peppers in China. Evolutionary Applications 8(1): 108118.

Doyer, L.C. (1938). Manual for the determination of seedborne diseases.

Gawade, S.B. (2013). Studies on seed borne pathogens of soybean (Glycine max (L.) Merrill), PhD Dissertation. Mahatma Phule Krishi Vidyapeeth, Maharashtra, India. 
Hemannavar, V. (2008). Studies on seed borne aspects of anthracnose of chilli and its management, MSc dissertation, University of Agricultural Sciences, Dharwad, India.

Hunupolagama, D.M., Chandrasekharan, N.V., Wijesundera, W.S.S., Kathriarachchi, H.S., Fernando, T.H.P.S. and Wijesundera, R.L.C. (2017). Unveiling members of Colletotrichum acutatum species complex causing Colletotrichum leaf disease of Hevea brasiliensis in Sri Lanka. Current Microbiology 74(6): 747-756.

Jayawardana, H.A.R.K., Weerahewa, H.L.D. and Saparamadu, M.D.J.S. (2015). Enhanced resistance to anthracnose disease in chili pepper (Capsicum annuum L.) by amendment of the nutrient solution with silicon. The Journal of Horticultural Science and Biotechnology 90(5): 557-562.

Kelaniyangoda, D.B., Salgadoe, A.S.A., Jayasekera, S.J.B.A. and Banda, R.G., 2011. Wilting of bell pepper (Capsicum annuum L.) causal organism isolation and a successful control approach. Asian Journal of Plant Pathology 5:155-162.

Khare, M.N. (1996). Methods to test seeds for associated fungi. Indian Phytopathology 49: 319-328.

Kumar, K., Singh, J. and Khare, A. (2004). Detection, location, transmission and management oflseed borne Colletotrichum dematium causing dieback and anthracnose in chili. Farm Science Journal 13(2): 152153.

Maden, S., Singh, D., Mathur, S.B. and Neergard, P. (1975). Detection and location of seed borne inoculum of Ascochytarabei and its transmission in chickpea. Seed Science and Technology 3: 667-671.

Mesta, R.K. (1996). Studies on fruit rot of chili caused by Colletotrichum capsici (Sydow.) Butler and Bisby.M.Sc.(Agri.) Thesis, University of Agricultural Sciences, Dharwad, India.

Mongkolporn, O. and Taylor, P.W.J. (2018). Chili anthracnose: Colletotrichum taxonomy and pathogenicity. Plant Pathology 67(6): 1255-1263.

Nahar, M.M.S., Mushtaq, M. and Pathan, I.H. (2004). Seed- borne mycoflora of Capsicum annuum imported from India. Pakistan Journal of Botany 36(1): 191-197.

Nagaraja,O. and Krishnappa,M. (2006). Detection of seed borne nature Cercospora guizoticola,

location and its transmission in niger [Guizotia abyssinica (L F). Cass]. Journal of Plant Disease Sciences 5(1): 1622.

Niaz, I. and Dawar, S. (2009). Detection of seed borne mycoflora in maize (Zea mays L.). Pakistan Journal of Botany 41(1): 443-451.

Padman, M. and Janardhana, G.R. (2012). Screening for inhibitory activities of essential oils on the growth of Colletotrichum gloeosporioides (Penz.) Penz. And Sacc., the causal agent of leaf spot disease of Murrayakoenigii L. Archives of Phytopathology and Plant Protection 45(13): 1575-1581.

Padman, M. and Janardhana, G.R. (2011). Occurrence and characterization of Colletotrichum gloeosporioides isolated from Murrayakoenigii. New York Science Journal 4(8): 70-76.
Perane, R.R. and Joi, M.B. (1988). Studies on seed borne infection of fruit rot and dieback of chilies. Journal of Maharashtra Agricultural University 13: 231-232.

Photita, W., Taylor, P.W.J., Ford, R., Hyde, K.D. and Lumyong, S. (2005). Morphological and molecular characterization of Colletotrichum species from herbaceous plants in Thailand. Fungal Diversity 18: 117-133.

Priyantha, M.G.D.L., Athukorala, A.R.J., Jayasinghe, J.A.V.J., Sato, M., and Takahashi, H. (2016). Seed borne pathogens associated with seed lots of major food crops of Sri Lanka. Annals of Sri Lanka Department of Agriculture 18: 26-27.

Rajapakse, R.G.A.S. and Ranasinghe, J.A.D.A.R. (2002). Development of variety screening method for anthracnose disease of chili (Capsicum annuum L.) under field conditions. Tropical Agricultural Research and Extension 5(1-2): 7-11.

Ranathunge, N.P., Mongkolporn, O., Ford, R. and Taylor, P.W.J. (2012). Colletotrichum truncatum Pathosystem on Capsicum spp: infection, colonization and defence mechanisms. Australasian Plant Pathology 41(5): 463-473.

Rathod, L.R.M.D., Jadhav, S.K., Mane, S.M., Muley, and Deshmukh, P.S. (2012). Seed borne mycoflora of legumes seeds. International Journal of Advanced Biotechnology and Research 3(1):530532 Available at: http://www.bipublication.com.

Sangchote, S. and Juangbhanich, P. (1984). Seed Transmission of Colletotrichumcapsici on Pepper (Capsicum spp.). Kasetsart Journal: Natural Science 18(1): 7-13.

Sangdee, A., Sachan, S. and Khankhum, S. (2011). Morphological, pathological and molecular variability of Colletotrichum capsici causing anthracnose of chili in the North-east of Thailand. African Journal of Microbiology Research 5(25): 4368-4372 Available online at: http://www. academicjournals.org/AJMR

Saxena, A., Raghuwanshi, R., Gupta, V.K. and Singh, H.B. (2016). Chilli anthracnose: The epidemiology and management. Frontiers in Microbiology 7, No. 1527.

Senanayake, D.M.J.B., Jayasinghe, J.E.A.R.M., Shilpi, S., Wasala, S.K. and Mandal, B. (2013). A new begomovirus-betasatellite complex is associated with chilli leaf curl disease in Sri Lanka. Virus Genes 46(1): 128-139.

Sharfun-Nahar, S.N., Mushtaq, M. and Pathan, I.H. (2004). Seed-borne mycoflora of Capsicum annuum imported from India. Pakistan Journal of Botany 36(1): 191-198.

Sharma, P.N., Kaur, M., Sharma, O.P., Sharma, P. and Pathania, A. (2005). Morphological, pathological and molecular variability in Colletotrichum capsici, the cause of fruit rot of chillies in the subtropical region of north-western India. Journal of Phytopathology 153(4): 232-237.

Vinaya, H., Rao, M.S.L., Yashoda, H. and 
Mohankumar, H.D. (2009). Status of seed borne incidence of anthracnose of chilli in northern Karnataka and evaluation of seed health testing methods for the detection of Colletotrichum capsici. Karnataka Journal of Agricultural Sciences 22(4): 807-809.

Walcott, R.R. (2003). Detection of seed borne pathogens. Horticultural Technology 13(1): 40-47.

Yesuf, M. and Sangchote, S. (2004). Seed transmission and epidemics of Colletotrichum lindemuthianum in the major common bean growing areas of Ethiopia (JanMar 2005). Kasetsart Journal: Natural Science 39: 3445. 